\title{
The Relationships of Self-concept, Academic Achievement and Future Pathway of First Year Business Studies Diploma Students
}

\author{
Siew-Fun Tang \\ Taylor's Business School, Taylor's University \\ No. 1, Jalan Taylor's, 47500 Subang Jaya, Selangor Darul Ehsan, Malaysia \\ Tel: 60-3-5629-5690Ｅ-mail: siewfun.tang@taylors.edu.my
}

Received: March 8, 2011 Accepted: May 25, $2011 \quad$ Published: December 1, 2011

doi:10.5539/ijps.v3n2p123 URL: http://dx.doi.org/10.5539/ijps.v3n2p123

\begin{abstract}
A student's academic achievement is impacted by various factors including the multidimensional self-concept. Students with higher levels of achievement are more likely to complete their current study and progress to the next level of study compared to their peers with lower levels of achievement. This study investigates the relationships of self-concept, academic achievement and future pathway of the first year business studies diploma students in a private university college. One hundred and forty three students participated in the study and responded to the Self Description Questionnaire II (SDQII) comprising of three academic facets (Mathematics, English and School) and four non-academic facets (appearance, physical ability, parent relation and peer relation). Multivariate analysis provided evidence that a student's academic self-concept, in particular the school self-concept, English self-concept and Mathematics self-concept strongly impact his or her academic achievement in the first semester. However, there was no significant relationship between self-concept (academic and non-academic) and a student's choice of pathway after completing the diploma programme.
\end{abstract}

Keywords: Self-concept, Academic achievement and future pathway

\section{Introduction}

Self-concept is perception of oneself about strength, weakness, state of mind, and value by social and environmental interactions (Huitt, 2004; Marsh \& Craven, 1997; Slavin, 2003). According to Brinthaupt and Lipka (1994), and Purkey and Novak (1996), human behaviour can be substantially explained by self-concept, which is influenced by our sense of identity, the judgements other people make of us and perceptions of social with other people. Besides that, parental upbringing, continuous failure, depression and internal self-critic also influence the development of one's self-concept (Aziz \& Jamaludin, 2009). Self-concept can be divided into two distinct factors; academic and non-academic self concepts (Marsh, 1990; Marsh \& Shavelson, 1985). Academic self-concept is the perception of oneself in academic activities in relation to specific subjects, teachers and school while non-academic self-concept is about perception of oneself in non-academic activities which includes their physical self and their relations with parents, friends, and community.

Most past researches showed relentless support towards the belief that there is a significant relationship between academic self-concept and academic achievement in secondary and post-secondary students (Cokley \& Patel, 2007; Gordon, 1997; Yara, 2010) but none could resolve the issue of whether academic self-concept affects academic achievement or rather academic achievement affects academic self-concept (Bryne, 1996; Hattie, 1992). Recent study by Yara (2010) on students' self-concept and Mathematics achievement in some secondary schools in Southwestern Nigeria revealed that students with good self-concept perform well in Mathematics. Cokley (2000) found that the grade point average was the best predictor of academic self-concept for students attending predominantly white colleges and universities. The meta-analysis conducted by Valentine et al. (2004) showed that the relationship is vice-versa. Marsh (1993) attested that while there is a relationship between self-concept and academic achievement, general self-concept and non-academic self concepts are not related to academic achievement.

\subsection{Research Purposes}

The present study aims to find the relationship between academic achievement and students' self-concept in several facets such as Mathematics, English, school, appearance, physical ability, parent relation and peer 
relation among first year business diploma students in a private university college. Since the literature on students' pathway after their first tertiary programme equivalence of the diploma programme in this study is scarce, the effects of these self-concepts on their chosen pathway after their study programme and the relationship between academic achievement and their chosen post-diploma pathway will also be investigated.

The population understudy is the business diploma students who possessed a low level of Sijil Pelajaran Malaysia (the Malaysian equivalent to the "O" Levels) qualification; minimum three credits in any subjects, as an entry requirement to higher education in Malaysia but they have moderate to high socio-economic status. In general, while majority are able to cope with their studies in the first semester, there are quite a number who failed more than half of the number of subjects taken. The results of this study could proffer guidance to academic planning especially in coordinating academic and non-academic activities to improve academic achievement and to boost students with low self-concept.

\subsection{Conceptual Framework}

The research conceptual framework was developed following from the academic and non-academic self-concept factors setting by Marsh and Shavelson (1985), and Marsh (1990). Academic self-concept is defined by the student's perception of themselves in academic competencies measured in three factors; Math self-concept (MAT), English self-concept (ENG) and college (or school) self-concept (COL). On the other hand, non-academic self-concept is defined by the student's perception of themselves in non-academic competencies in four factors; physical appearance self-concept (APP), physical ability self-concept (ABI), parent relation self-concept (PAR) and peer relation self-concept (PER).

Academic achievement is measured by the achievement score from five subjects usually taken by students in their first semester. The subjects are Accounting 1 (Acc), Introduction to Business (Bus), Computer Applications and Data Processing (Com), English 1 (Eng), and Microeconomics (Mic). After completion of the diploma programme, students have two choices of pathway; either to work (or start their own business) or continue their studies to the degree level. The conceptual model for this study is illustrated in Figure 1.

\section{Insert Figure 1 here}

\section{Method}

\subsection{Research Participants and Data Collection}

143 first year business studies diploma students in a private university college participated voluntarily in this study. The participants are post-secondary students whose age ranged from 18-19 years old. Permissions were obtained from the lecturers for administering the questionnaire during their tutorial classes. The participants were briefed on the purpose of the study and told of their rights to withhold their participation during or after they had completed the questionnaire. On average, the participants completed the questionnaire in no more than 15 minutes.

\subsection{Measures}

A 64-item survey questionnaire comprising three academic subscales (English, Math, and School) and four non-academic subscales (Appearance, Physical Ability, Parents Relation, and Peer Relation) of the Self-Description Questionnaire II (Marsh, 1992) was used in this study. The seven subscales had several items, measuring the academic self-concept (English self-concept, Math self-concept, and school self-concept) and the non-academic self-concept (appearance self-concept, physical ability self-concept, parent relation self-concept, and peer relation self-concept). Each item was measured on a six-point Likert scale with $1=$ False, not like me at all to $6=$ True, very much like me. The reliability (Cronbach's Alpha) of each subscale is $0.922,0.860,0.835$, $0.862,0.800,0.880$ and 0.744 respectively after removing items with corrected item-total correlations below 0.3 .

The participants were also asked to report their year of birth, gender, student identification number and their desired future pathway after completing their diploma course. They were assured of the confidentiality of their responses which would be used for research and programme development purposes only and would not be used in any way to refer to them as an individual. It was emphasized that their willingness to reveal their student identification number was crucial to retrieve their academic results for data analysis.

\section{Research Findings}

The students' performance in all five first semester subjects, namely Accounting 1 (Acc, $M=61.92, S D=16.48$ ), Introduction to Business (Bus, $M=63.21, S D=15.85$ ), Computer Applications and Data Processing (Com, $M=$ $61.99, S D=15.48$ ), English 1 (Eng, $M=56.74, S D=9.50)$ and Microeconomics (Mic, $M=55.99, S D=14.74$ ) were evaluated. 
The researcher decided to separate English 1 (now, termed as English) from the other four subjects because it is lowly correlated with the rest. An examination of the correlation matrix for four subjects, Acc, Bus, Com and Mic indicated that correlation for each subject with at least one other subject is between 0.3-0.9. In factor analysis, the Bartlett's test of sphericity was significant and that the Kaiser-Meyer-Olkin (KMO) measure of sampling adequacy was 0.851 , far greater than 0.6 . A single factor was extracted that explained $79 \%$ of the total variance in the four subjects. The composite reliability (CR) value was 0.937 . Thus a summated score (mean) was taken to represent the student's academic achievement (ACH) (Hair et al., 2006). To ease computations, the data in each subscale were reduced to one factor in Factor Analysis and the summary results in Table 1 below shows that the extraction of one factor from each self-concept is justified.

\section{Insert Table 1 here}

Pearson Correlation Analysis (see Table 2) revealed that there is a significant negative relationship between Math self-concept and English self-concept where $r=-.299, p<.05$. It was found that a significant positive relationship exists between Math self-concept and school self-concept $(r=.245, p<.05)$. Similarly, the relationship between English self-concept and school self-concept is also significantly positive $(r=.211, p<.05)$. Results of the correlation analysis indicate that higher Math self-concept scores are related with higher school self-concept scores but lower English self-concept scores. Meanwhile, higher English self-concept scores are associated with higher school self-concept scores.

\section{Insert Table 2 here}

As for the non-academic self-concepts, each of them has a significant positive relationship with any one of the other non-academic self-concept. Therefore, a high score in one non-academic self-concept is associated with a high score in another non-academic self-concept. However, there is no significant relationship between Math self-concept and Appearance self-concept, between English self-concept and parent relation self-concept, and between English self-concept and peer relation self-concept.

$40.6 \%$ of the participants expressed that they would like to work or start their own business after completing their business diploma programme while $59.4 \%$ want to continue their study in the degree programme. The means and standard deviations of academic achievement and English score for different chosen pathways are given in Table 3.

Insert Table 3 here

Given that Levene's test has a probability greater than .05 , we can assume that the population variances are relatively equal. Therefore, we can use the $t$-test to test for equality of means in the students' academic achievement and English score for different chosen pathways. The two-tail significance for the academic achievement and English score in Table 4 indicate that $t(141)=-.198, p>.05$ and $t(138)=0.449, p>.05$ respectively. Therefore, we conclude that academic achievement and English score respectively do not differ significantly with differences in student chosen pathway.

\section{Insert Table 4 here}

Logistic regression is employed to run a model predicting the outcome variable, post-diploma pathway (PDP), using academic achievement (ACH) and English score (Eng). The aim is to associate the chosen pathway with academic achievement and English score. It is assumed that a linear relationship between the transformed outcome variable PDP and the predictor variables, ACH and Eng. Since there are multiple categories, a base category is chosen as the comparison group. Here, continue to study (pathway =1) after completing the diploma programme is chosen.

The likelihood ratio test (see Table 5) indicated that the chi-square value of 0.398 with a $p$-value of more than 0.05 tells us that the model as a whole does not fit significantly.

\section{Insert Table 5 here}

A comparable statistic to $R$-squared does not exist in logistic regression analysis. This is because the model estimates are maximum likelihood estimates generated through an iterative process and they are not calculated to minimize variance. Hence, the ordinary least squares (OLS) approach to goodness-of-fit does not apply and pseudo $R$-squared can be used to evaluate the goodness-of-fit of the logistic model. These are "pseudo" $R$-squareds because they range from 0 to 1 , just like the $R$-squareds, with higher values indicating better model fit. However, their interpretation differs from an OLS $R$-squared because different pseudo $R$-squareds can arrive at very different values. In this study, three measures of pseudo $R$-squared yielded very low values; Cox and 
Snell's $=0.003$, Nagelkerke's $=0.004$ and McFadden's $=0.002$ and these confirmed that the data do not fit into the logistic model.

The likelihood ratio tests results in Table 5 show that both the academic achievement and English score are statistically insignificant. Therefore, a student's choice of post-diploma pathway does not depend on their academic achievement or their English score.

Linear regression is employed to determine the contribution of the academic and non-academic self-concepts to students' academic achievement and English score respectively in the first semester of their business diploma programme, and whether they are salient predictors. As the researcher decides in which order to enter the independent variables into the model based on past research, hierarchical multiple regression is used. The set of academic self concepts were entered first (read as block 1) and then followed by the set of non-academic self-concepts (read as block 2). Forced entry was selected for the first block and a stepwise method for the second block since there is a lack of research in the effects of non-academic self-concepts on academic achievement.

Table 6 shows that the academic self-concepts on their own contribute $39.6 \%$ and $24.2 \%$ of the variance in academic achievement and English score respectively (see models 1 and 3). However, for the final models (models 2 and 4), these values increase to $42.3 \%$ and 27.9\% variation in academic achievement and English score respectively. Therefore, whatever significant variables (using stepwise linear regression) enter the model in block 2 account for an extra $2.7 \%$ of the variance in academic achievement which is highly significant as indicated by the $F$-value of 24.559 (see Table 7). Similarly, an additional of 3.7\% of the variance in English score was also significant with $F$-value 12.86. The adjusted $R^{2}$ gives us some idea how well our model generalises and ideally we would like this value to be the same, or very close to, the value of $R^{2}$. The difference in the final model for each of the academic achievement (model 2) and English score (model 4) respectively is a fair bit (.423-.406, or $1.7 \%$ and $.279-.257$, or $2.2 \%$ ). This shrinkage means that if the model for academic achievement and model for English score were derived from the population rather than a sample, it would account for approximately $1.7 \%$ and $2.2 \%$ respectively less variance in the outcome.

\section{Insert Table 6 here}

Insert Table 7 here

The Durban-Watson statistic is calculated to test the correlation between errors. The test statistic can vary from 0 to 4, with a value of 2 meaning that the residuals are uncorrelated. As a conservative rule of thumb, Field (2009) suggests that values less than 1 or greater than 3 are definitely cause for concern. The closer the value to 2 , the better and for these data (see Table 6), the value is 1.51 for dependent variable academic achievement and 1.64 for English score, indicating that the assumption of independent errors is tenable for both cases.

An examination of $t$-values in Table 8 indicates that the Math self-concept, English self-concept, college self-concept and peer relation self-concept contribute significantly to the students' academic achievement. The appearance, physical ability and parent relation self-concepts failed to meet the selection criteria. As for English score, all the academic self-concepts and appearance self-concept are the salient predictors. The $b$ values tell us about the relationship between the dependent variable and each predictor, and to what degree each predictor affects the outcome if the effects of all other predictors are held constant. If the value is positive we can tell that there is a positive relationship between the predictor and the outcome whereas a negative coefficient represents a negative relationship. Thus, for the data in this study, as Math self-concept and college self-concept increase, academic achievement improves. However, as English self-concept and peer self-concept increase, academic achievement decreases. On the other hand, as each of the academic self-concepts of English and college (school) increases, English score also increases but high appearance self-concept will result in low English score. Hence, school self-concept and English self-concept had greater impact than the other two significant predictors for both the academic achievement and English score.

\section{Insert Table 8 here}

Tolerance and the Variance Inflation Factor (VIF) are the two collinearity diagnostic statistics used to assess multicollinearity. A small tolerance value indicates that the variable under consideration is almost a perfect linear combination of the independent variables already in the equation and that it should not be added to the regression equation. The VIF is 1 /tolerance and takes a value greater than or equal to 1 . It measures the impact of collinearity among the independent variables in a regression model. According to O'Brien (2007), a tolerance of less than 0.20 or 0.10 and/or a VIF of 5 or 10 and above indicates a multicollinearity problem. In this study, all 
independent variables involved have acceptable tolerance and VIF values as shown in Table 8, indicating the problem of multicollinearity does not exit.

The scatterplots of residuals against predicted values for academic achievement and English score respectively in Figure 2 show that there is no clear relationship between the residuals and the predicted values, consistent with the assumption of linearity.

\section{Insert Figure 2 here}

Both the normal plots of regression standardised residuals (see Figure 3) for the academic achievement and English score respectively indicate a relatively normal distribution for each.

\section{Insert Figure 3 here}

The normal plot of regression standardised residuals (see Figure 2) for the dependent variable, academic achievement also indicates a relatively normal distribution.

The likelihood ratio tests from logistic regression analysis in Table 9 revealed that all the academic and non-academic self-concepts are not significant predictors of students' choice of pathway upon completion of their business diploma programme.

Insert Table 9 here

\section{Discussion}

Multivariate analysis provided evidence that a student's academic self-concept, in particular the college self-concept, English self-concept and Math self-concept strongly impact his or her academic achievement in the first semester. Like many other countries, in Malaysia, a student develops his or her academic achievement from young and continuously develops it in the education system for a long time. It is important that the college creates a supportive environment for student to continuously improve their self-concept which would promote higher academic achievement. In addition, each of the non-academic self-concepts; peer relation self-concept and appearance self-concept affect academic achievement for non-language subjects and English scores respectively. This is supported by the importance of non-academic self-concept in student's real life (William, 1993) in adjusting to adulthood. Peer relation self-concept is an important social factor during class and out-of-class. While this may enhance learning among peers but the negative relationship between academic achievement and peer relation self-concept in this study may be explained as overly dependent on peers in doing group assignments or coursework will daunt independent learning and encourage social loafing. On the other hand, students who perceived themselves as better looking than others (higher appearance self-concept) may be over confident and neglect the academic aspects when doing verbal presentations in individual and group works which contribute largely to the English coursework.

It is recommended that school administrators and lecturers organise activities to improve student positive self-concepts. In the classroom, the lecturers play an important role in reflecting student's performance and activity both in academic and non-academic areas. Praises and constructive feedback help increase the student self-concept. Studies by Hay (2005), and Roberson and Steward (2006) attest to the beneficial results of using reflection method. Similarly, Sommer and Baumeister (2002) pointed out that persistence following failure is likely to lead to improved performance in academic and professional situations. Their study findings concurred with Dodgson and Wood (1998), and Greenberg et al. (1992) that a positive self-concept is beneficial for poor performance following failure and disappointment. This is particularly true for participants of this study who had only minimum qualification to enter the current study programme. Hence, a positive self-concept will promote better academic achievement and future success.

Furthermore, students look up at their lecturers as role models in their demeanour and interest for the subject. Lecturers who are able to incorporate self-attribution and motivational strategies in their lessons can influence students' learning persistence which will in turn boost student achievement. Lecturers who act as mentors can play a more active role in assisting students with low self-concepts who are at risk and can contribute to their graduating and progressing to their chosen pathway by building a relationship with them. These are imperative criteria in selecting lecturers to teach in the diploma programme. As for non-academic activities, group activities which encourage real social interactions among the students and with lecturers are essential for self-concept enhancement. However, the level of difficulty in activities must be appropriate to encourage active participation from all students and to avoid social loafing.

Non-significance of relationship between self-concept (academic and non-academic) and a student's choice of pathway after completing the diploma program and non-dependence of student's choice of post-diploma pathway 
on their academic achievement or their English score may be typical among diploma students. Students who enrolled in the business diploma programme may have made up their mind on the pathway after diploma due to parental or peer influence. Hence, the future pathway of diploma students is not affected by their academic achievement or self-concepts. Thus, it is recommended that activities in relation to career services and conversion initiatives should be organized and targeted to the correct group. The participants should be chosen based on their future pathway and not according to academic capability.

\section{References}

Aziz, Y., \& Jamaludin, R. (2009). The relationship between self-concept and communication skills towards academic achievement among secondary school students in Johor Bahru. International Journal of Psychological Studies, 1(2), 25-34

Brinthaupt, T., \& Lipka, R. (1994). Changing the self: Philosophies, techniques and experiences. Albany: State University of New York Press.

Bryne, B. 1996. Academic self-concept: Its structure, measurement and relation to academic achievement, In Bracken (Ed.). Handbook of self-concept: Developmental, social and clinical considerations (pp. 287-316). New York.

Cokley, K. (2000). An investigation of academic self-concept and its relationship to academic achievement in African American College students. Journal of Black Psychology, 26(2), 148-164. http://dx.doi.org/10.1177/0095798400026002002

Cokley, K., \& Patel, N. (2007). A psychometric investigation of the academic self-concept of Asian American college students. Educational and Psychological Measurement, 67, 88-99. http://dx.doi.org/10.1177/0013164406288175

Dodgson, P.G., \& Wood, J. V. (1998). Self-esteem and the cognitive accessibility of strengths and weaknesses after failure. Journal of Personality and Social Psychology, 75, 178-197. http://dx.doi.org/10.1037/0022-3514.75.1.178

Field, A.P. (2009). Discovering statistics using SPSS: and sex and drugs and rock ' $n$ ' roll (3rd ed.). London: Sage.

Gordon, D. (1997). The relationships among academic self-concept, academic achievement, and persistence with self-attribution, study habits, and perceived school environment. [Online] Available: http://docs.lib.purdue.edu/dissertations/AAI9818955/ (August 8, 2010).

Greenberg, J., Solomon, S., Pyszczynski, T., Rosenblatt, A., Burling, J., Lyon, D., Simon, L., \& Pinel, E. (1992).Why do people need self-esteem? Converging evidence that self-esteem serves an anxiety-buffering function. Journal of Personality and Social Psychology, 63, 913-922. http://dx.doi.org/10.1037/0022-3514.63.6.913

Hair, J. F., William, C. B., Barry, B. J., Rolph, E. A., \& Ronald, L. T. (2006). Multivariate Data Analysis (6th ed.). NJ: Pearson Education Inc.

Hattie, J. (1992). Self-concept. London: Erlbaum.

Hay, I. (2005). Facilitating children's self-concept: A rationale and evaluative study. Australian Journal of Guidance \& Counselling, 15, 60-67. http://dx.doi.org/10.1375/ajgc.15.1.60

Huitt, W. (2004). Becoming a Brilliant Star: An introduction. Presentation at the Forum for Integrated Education and Educational Reform sponsored by the Council for Global Integrative Education, Santa Cruz, CA. [Online] Available: http://www.edpsycinteractive.org/ brilstar/brilstarintro_s.pdf (June 8, 2010).

Marsh, H. W. (1993). Academic self-concept: Theory, measurement and research. In J. Suls (Ed.), Psychological perspectives on the self. (pp. 59-98). NJ: Erlbaum.

Marsh, H. W. (1992). Self-Description Questionnaire II: Manual. New South Wales, Australia: University of Western Sydney, Macarthur, Faculty of Education, Publication Unit.

Marsh, H. W. (1990). A multidimensional, hierarchical self-concept: Theoretical and empirical justification. Educational Psychology Review, 2, 77-172. http://dx.doi.org/10.1007/BF01322177

Marsh, H. W., \& Craven, R. G. (1997). Self-concept: Beyond the dustbowl. In G. Phye (Ed.), Handbook of classroom assessment: Learning, achievement, and adjustment. (pp. 131-198). Orlando, FL: Academic Press. 
Marsh, H. W., \& Shavelson, R. J. (1985). Self-concept: Its multifaceted, hierarchical structure. Educational Psychologist, 20, 107-125. http://dx.doi.org/10.1207/s15326985ep2003_1

O'Brien, R. M. (2007). A Caution Regarding Rules of Thumb for Variance Inflation Factors. Quality and Quantity, 41(5), 673-690. http://dx.doi.org/10.1007/s11135-006-9018-6

Purkey, W., \& Novak, J. (1996). Inviting school success: A self-concept approach to teaching and learning (3rd ed.). Belmont, CA: Wadsworth.

Roberson, Q. M., \& Stewart, M. M. (2006). Understanding the motivational effects of procedure and informational justice in feedback processes. British Journal of Psychology, 97, 281-298. http://dx.doi.org/10.1348/000712605X80146

Slavin, R. E. (2003). Educational psychology: Theory and practice (7th ed.). Boston, MA: Allyn and Bacon.

Sommer, K.L., \& Baumeister, R. F. (2002). Self-evaluation, persistence and performance following implicit rejection: The role of trait self-esteem. Personality and Social Psychology Bulletin, 28, 926-938

Valentine, J. C., DuBois, D.L., \& Cooper, H. (2004). The relations between self-beliefs and academic achievement: A systematic review. Educational Psychologist, 39, 111-133. http://dx.doi.org/10.1207/s15326985ep3902_3

William, J. E. (1993). Nonacademic self-concept and gender as achievement predictors. [Online] Available: http://eric.ed.gov/ERICDocs/data/ericdocs2/content_storage_01/ 0000000b/80/23/85/7f.pdf (October 25, 2009).

Yara, P. O. (2010). Students' self-concept and Mathematics achievement in some secondary schools in southwestern Nigeria. European Journal of Social Sciences, 13 (1). 127-132

Table 1. Factor analysis for each self-concept

\begin{tabular}{|l|c|c|c|c|c|c|}
\hline Self-concept & $\begin{array}{c}\text { Final } \\
\text { number of } \\
\text { items in } \\
\text { subtest }\end{array}$ & $\begin{array}{c}\text { KMO } \\
\text { measure of } \\
\text { Sampling } \\
\text { Adequacy }\end{array}$ & $\begin{array}{c}\text { Bartlett's } \\
\text { Test of } \\
\text { Sphericity }\end{array}$ & $\begin{array}{c}\text { Total } \\
\text { variance } \\
\text { explained }\end{array}$ & $\begin{array}{c}\text { Factor } \\
\text { loadings }\end{array}$ & $\begin{array}{c}\text { Internal } \\
\text { reliability } \\
\text { (Cronbach's } \\
\text { Alpha) }\end{array}$ \\
\hline Math (MAT) & 7 & 0.908 & .000 & $69.24 \%$ & $0.652-0.917$ & 0.921 \\
English (ENG) & 5 & 0.863 & .000 & $68.52 \%$ & $0.709-0.906$ & 0.880 \\
College (COL) & 5 & 0.816 & .000 & $62.54 \%$ & $0.751-0.872$ & 0.849 \\
Appearance (APP) & 6 & 0.849 & .000 & $60.16 \%$ & $0.642-0.877$ & 0.862 \\
Physical Abilities (ABI) & 6 & 0.790 & .000 & $51.07 \%$ & $0.527-0.866$ & 0.800 \\
Parent Relation (PAR) & 8 & 0.892 & .000 & $54.97 \%$ & $0.604-0.817$ & 0.880 \\
Peer Relation (PER) & 4 & 0.749 & .000 & $57.84 \%$ & $0.666-0.843$ & 0.751 \\
\hline
\end{tabular}

Table 2. Correlations between self-concepts

\begin{tabular}{|c|c|c|c|c|c|c|c|c|}
\hline & & $\begin{array}{c}\text { Math } \\
\text { (MAT) }\end{array}$ & $\begin{array}{l}\text { English } \\
\text { (ENG) }\end{array}$ & $\begin{array}{l}\text { College } \\
\text { (COL) }\end{array}$ & $\begin{array}{l}\text { Appearance } \\
\text { (APP) }\end{array}$ & $\begin{array}{l}\text { Phy. } \\
\text { Ability } \\
\text { (ABI) }\end{array}$ & $\begin{array}{l}\text { Parent } \\
\text { Rel. } \\
\text { (PAR) }\end{array}$ & $\begin{array}{c}\text { Peer } \\
\text { Rel. } \\
\text { (PER) }\end{array}$ \\
\hline Math & Pearson Correlation & 1 & $-.299^{* *}$ & $.245^{* *}$ & .072 & $.181^{*}$ & $.241^{* *}$ & $.230^{* *}$ \\
\hline (MAT) & Sig. (1-tailed) & & .000 & .002 & .198 & .016 & .002 & .003 \\
\hline English & Pearson Correlation & $-.299^{* *}$ & 1 & $.211^{* *}$ & $.330^{* *}$ & $.258^{* *}$ &.- .042 & .061 \\
\hline (ENG) & Sig. (1-tailed) & .000 & & .006 & .000 & .001 & .310 & .237 \\
\hline College & Pearson Correlation & $.245^{* *}$ & $.211^{* *}$ & 1 & $.274^{* *}$ & $.145^{*}$ & $.250^{* *}$ & $.365^{* *}$ \\
\hline$(\mathrm{COL})$ & Sig. (1-tailed) & .002 & .006 & & .000 & .042 & .001 & .000 \\
\hline Appearance & Pearson Correlation & .072 & $.330^{* *}$ & $.274^{* *}$ & 1 & $245^{* *}$ & $215^{* *}$ & $.150^{*}$ \\
\hline (APP) & Sig. (1-tailed) & .198 & .000 & .000 & & .002 & .005 & .037 \\
\hline Phy.Ability & Pearson Correlation & $.181^{*}$ & $.258^{* *}$ & $.145^{*}$ & $245^{* *}$ & 1 & $.157^{*}$ & $.152^{*}$ \\
\hline$(\mathrm{ABI})$ & Sig. (1-tailed) & .016 & .001 & .042 & .002 & & .031 & .036 \\
\hline Parent Rel. & Pearson Correlation & $241^{* *}$ & -.042 & $.250^{* *}$ & $.215^{* *}$ & $.157^{*}$ & 1 & $.139^{*}$ \\
\hline (PAR) & Sig. (1-tailed) & .002 & .310 & .001 & .005 & .031 & & .049 \\
\hline Peer Rel. & Pearson Correlation & $230^{* *}$ & .061 & $.365^{* *}$ & $.150^{*}$ & $.152^{*}$ & $.139^{*}$ & 1 \\
\hline (PER) & Sig. (1-tailed) & .003 & .237 & .000 & .037 & .036 & .049 & \\
\hline
\end{tabular}

**. Correlation is significant at the 0.01 level (1-tailed).**. Correlation is significant at the 0.05 level (1-tailed). 
Table 3. Academic achievement (4 subjects) and English score for different chosen pathways

\begin{tabular}{|l|l|c|c|c|}
\hline & Chosen Post-Diploma Pathway (PDP) & N & Mean & Std. Deviation \\
\hline Academic achievement & Work/start business & 58 & 60.46 & 14.041 \\
& ACH) & 85 & 60.93 & 13.862 \\
\hline English score (Eng) & Continue to study & 58 & 57.17 & 9.480 \\
& Cork/start business & 82 & 56.44 & 9.556 \\
\hline
\end{tabular}

Table 4. Independent samples tests

\begin{tabular}{|c|c|c|c|c|c|c|c|c|c|c|}
\hline & \multicolumn{9}{|c|}{ Test for Equality } \\
\hline & & \multicolumn{2}{|c|}{$\begin{array}{c}\text { Variances } \\
\text { (Levene's Test) }\end{array}$} & \multicolumn{7}{|c|}{ Means ( $t$-test) } \\
\hline & & \multirow[b]{2}{*}{$F$} & \multirow[b]{2}{*}{ Sig. } & \multirow[b]{2}{*}{$t$} & \multirow[b]{2}{*}{$\mathrm{df}$} & \multirow{2}{*}{$\begin{array}{c}\text { Sig. } \\
\text { (2-tailed) }\end{array}$} & \multirow{2}{*}{$\begin{array}{l}\text { Mean } \\
\text { Diff. }\end{array}$} & \multirow{2}{*}{$\begin{array}{c}\text { Std. } \\
\text { Error } \\
\text { Diff. }\end{array}$} & \multicolumn{2}{|c|}{$\begin{array}{l}95 \% \text { Conf. Int. of } \\
\text { the Diff. }\end{array}$} \\
\hline & & & & & & & & & Lower & Upper \\
\hline $\begin{array}{l}\text { Academic } \\
\text { Ach. }(\mathrm{ACH})\end{array}$ & $\begin{array}{l}\text { Equal var. } \\
\text { assumed }\end{array}$ & .004 & .950 & -.198 & 141 & .844 & -.469 & 2.373 & -5.161 & 4.223 \\
\hline $\begin{array}{l}\text { English } \\
\text { score } \\
\text { (Eng) }\end{array}$ & $\begin{array}{l}\text { Equal var. } \\
\text { assumed }\end{array}$ & .003 & .959 & .449 & 138 & .654 & .733 & 1.634 & -2.498 & 3.965 \\
\hline
\end{tabular}

Table 5. Model fitting

\begin{tabular}{|l|c|c|c|c|}
\hline \multirow{2}{*}{ Model } & \multicolumn{2}{|c|}{ Model Fitting Criteria } & \multicolumn{2}{c|}{ Likelihood Ratio Tests } \\
\cline { 2 - 5 } Intercept Only & -2 Log Likelihood & Chi-Square & $\mathrm{df}$ & Sig. \\
Final & 188.560 & & & \\
Effect & 188.163 & .398 & 2 & .820 \\
Intercept & & & & .569 \\
Academic achievement (ACH) & 188.487 & .324 & 1 & .660 \\
English score (Eng) & 188.356 & .194 & 1 & .560 \\
\hline
\end{tabular}

The chi-square statistic is the difference in -2 log-likelihoods between the final model and a reduced model. The reduced model is formed by omitting an effect from the final model. The null hypothesis is that all parameters of that effect are 0 . 
Table 6. Model summary for academic achievement and English score using hierarchical linear regression

\begin{tabular}{|c|c|c|c|c|c|c|c|c|c|c|}
\hline \multirow[b]{2}{*}{ Model } & \multirow[b]{2}{*}{$R$} & \multirow[b]{2}{*}{$\begin{array}{c}R \\
\text { Square }\end{array}$} & \multirow[b]{2}{*}{$\begin{array}{l}\text { Adjusted } \\
R \text { Square }\end{array}$} & \multirow[b]{2}{*}{$\begin{array}{l}\text { Std. Error } \\
\text { of the } \\
\text { Estimate }\end{array}$} & \multicolumn{5}{|c|}{ Change Statistics } & \multirow[b]{2}{*}{$\begin{array}{l}\text { Durbin- } \\
\text { Watson }\end{array}$} \\
\hline & & & & & $\begin{array}{c}R \\
\text { Square } \\
\text { Change }\end{array}$ & $\begin{array}{c}F \\
\text { Change }\end{array}$ & df1 & $\mathrm{df} 2$ & $\begin{array}{l}\text { Sig. } F \\
\text { Change }\end{array}$ & \\
\hline 1 & .629 & .396 & .383 & 10.96778 & .396 & 29.535 & 3 & 135 & .000 & \\
\hline 2 & .650 & .423 & .406 & 10.76199 & .027 & 6.212 & 1 & 134 & .014 & 1.51 \\
\hline 3 & .492 & .242 & .225 & 8.360 & .242 & 14.265 & 3 & 134 & .000 & \\
\hline 4 & .528 & .279 & .257 & 8.185 & .037 & 6.797 & 1 & 133 & .010 & 1.64 \\
\hline
\end{tabular}

Model 1: Dependent Variable: ACH, Predictors: (Constant), COL, ENG, MAT

Model 2: Dependent Variable: ACH, Predictors: (Constant), COL, ENG, MAT, PER

Model 3: Dependent Variable: Eng, Predictors: (Constant), COL, ENG, MAT

Model 4: Dependent Variable: Eng, Predictors: (Constant), COL, ENG, MAT, APP

Table 7. ANOVA for academic achievement and English score

\begin{tabular}{|cl|ccccc|}
\hline \multicolumn{2}{|c|}{ Model } & Sum of Squares & df & Mean Square & $F$ & Sig. \\
\hline 1 & Regression & 10658.361 & 3 & 3552.787 & 29.535 & .000 \\
& Residual & 16239.445 & 135 & 120.292 & & \\
& Total & 26897.807 & 138 & & & .000 \\
\hline 2 & Regression & 11377.863 & 4 & 2844.466 & 24.559 & \\
& Residual & 15519.944 & 134 & 115.820 & & .000 \\
& Total & 26897.807 & 138 & & & \\
\hline 3 & Regression & 2990.953 & 3 & 996.984 & 14.265 & .000 \\
& Residual & 9365.405 & 134 & 69.891 & & \\
& Total & 12356.358 & 137 & & & \\
\hline 4 & Regression & 3446.291 & 4 & 861.573 & & \\
& Residual & 8910.067 & 133 & 66.993 & & \\
& Total & 12356.358 & 137 & & & \\
\hline
\end{tabular}


Table 8. Hierarchical linear regression models for academic achievement and English score

\begin{tabular}{|c|c|c|c|c|c|c|c|c|}
\hline & & \multicolumn{2}{|c|}{$\begin{array}{l}\text { Unstandardized } \\
\text { Coefficients }\end{array}$} & \multicolumn{3}{|c|}{$\begin{array}{l}\text { Standardized } \\
\text { Coefficients }\end{array}$} & \multicolumn{2}{|c|}{$\begin{array}{l}\text { Collinearity } \\
\text { Statistics }\end{array}$} \\
\hline \multicolumn{2}{|c|}{ Model } & $b$ & Std. Error & Beta & $t$ & Sig. & Tolerance & VIF \\
\hline \multirow[t]{4}{*}{1} & (Constant) & 60.949 & .930 & & 65.513 & .000 & & \\
\hline & MAT & 1.727 & 1.033 & .124 & 1.671 & .097 & .817 & 1.223 \\
\hline & ENG & -5.877 & 1.025 & -.419 & -5.735 & .000 & .836 & 1.196 \\
\hline & $\mathrm{COL}$ & 6.611 & 1.004 & .476 & 6.585 & .000 & .855 & 1.169 \\
\hline \multirow[t]{5}{*}{2} & (Constant) & 60.972 & .913 & & 66.788 & .000 & & \\
\hline & MAT & 2.136 & 1.027 & .153 & 2.079 & .039 & .797 & 1.255 \\
\hline & ENG & -5.769 & 1.007 & -.412 & -5.732 & .000 & .834 & 1.199 \\
\hline & $\mathrm{COL}$ & 7.391 & 1.034 & .532 & 7.150 & .000 & .777 & 1.287 \\
\hline & PER & -2.464 & .988 & -.178 & -2.492 & .014 & .844 & 1.185 \\
\hline \multirow[t]{4}{*}{3} & (Constant) & 56.743 & .712 & & 79.733 & .000 & & \\
\hline & MAT & -.007 & .793 & .000 & -.009 & .993 & .811 & 1.233 \\
\hline & ENG & 3.607 & .787 & .380 & 4.585 & .000 & .824 & 1.213 \\
\hline & $\mathrm{COL}$ & 2.305 & .774 & .243 & 2.977 & .003 & .851 & 1.175 \\
\hline \multirow[t]{5}{*}{4} & (Constant) & 56.743 & .697 & & 81.440 & .000 & & \\
\hline & MAT & .251 & .783 & .026 & .320 & .749 & .798 & 1.253 \\
\hline & ENG & 4.269 & .811 & .450 & 5.264 & .000 & .743 & 1.345 \\
\hline & $\mathrm{COL}$ & 2.650 & .769 & .279 & 3.444 & .001 & .826 & 1.211 \\
\hline & APP & -1.996 & .766 & -.210 & -2.607 & .010 & .834 & 1.199 \\
\hline
\end{tabular}

Models 1 \& 2, Dependent Variable: ACH

Models 3 \& 4, Dependent Variable: Eng

Table 9. Likelihood ratio tests

\begin{tabular}{|l|c|ccc|}
\hline \multirow{2}{*}{ Effect } & Model Fitting Criteria & \multicolumn{3}{|c|}{ Likelihood Ratio Tests } \\
\cline { 2 - 5 } Intercept & -2 Log Likelihood of Reduced Model & Chi-Square & $\mathrm{df}$ & Sig. \\
MAT & 184.385 & 6.463 & 1 & .011 \\
ENG & 179.212 & 1.291 & 1 & .256 \\
COL & 177.952 & .030 & 1 & .862 \\
APP & 179.975 & 2.053 & 1 & .152 \\
ABI & 180.740 & 2.818 & 1 & .093 \\
PAR & 178.280 & .358 & 1 & .549 \\
PER & 179.920 & 1.998 & 1 & .157 \\
\hline
\end{tabular}

The chi-square statistic is the difference in -2 log-likelihoods between the final model and a reduced model. The reduced model is formed by omitting an effect from the final model. The null hypothesis is that all parameters of that effect are 0 . 


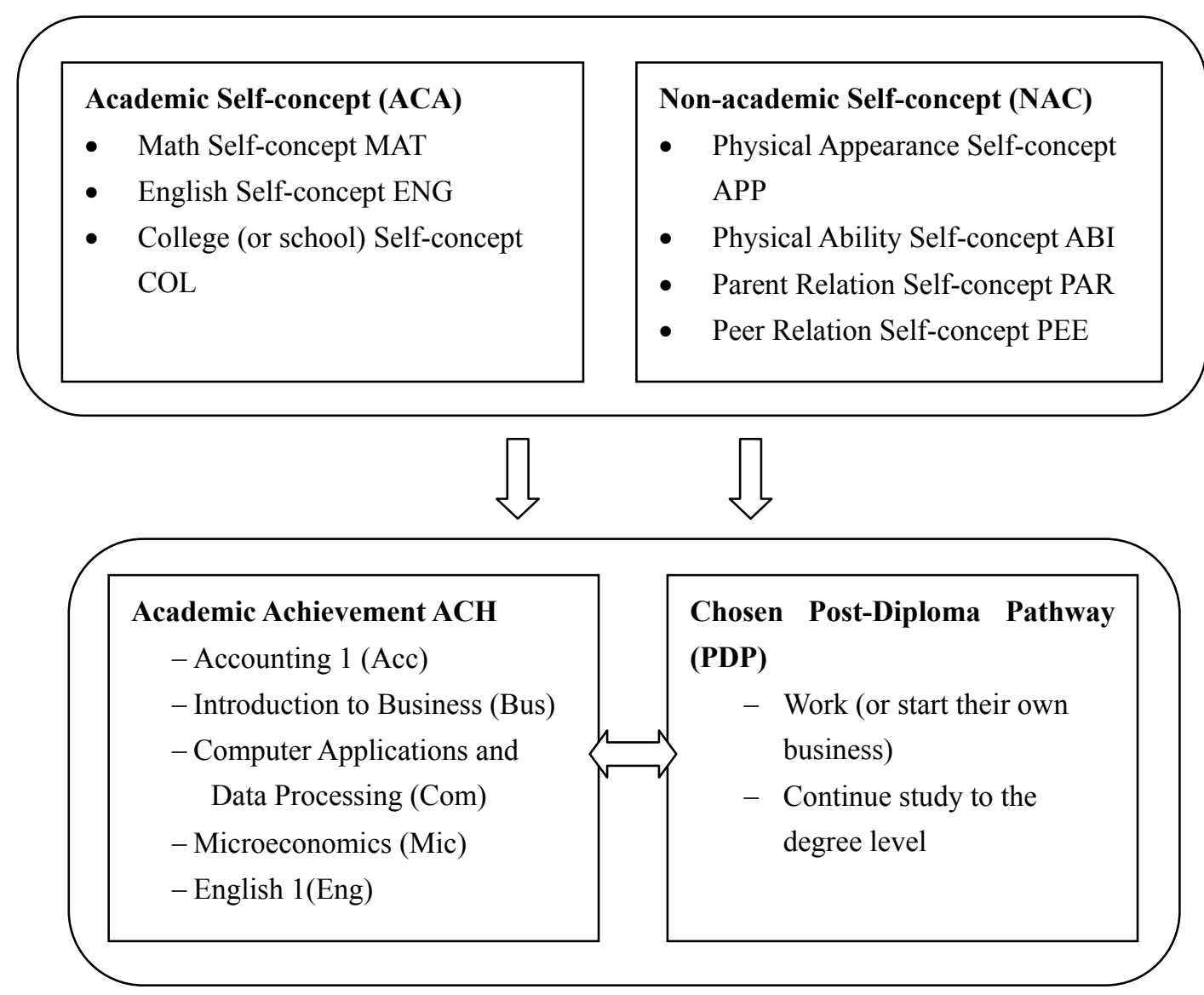

Figure 1. Conceptual framework

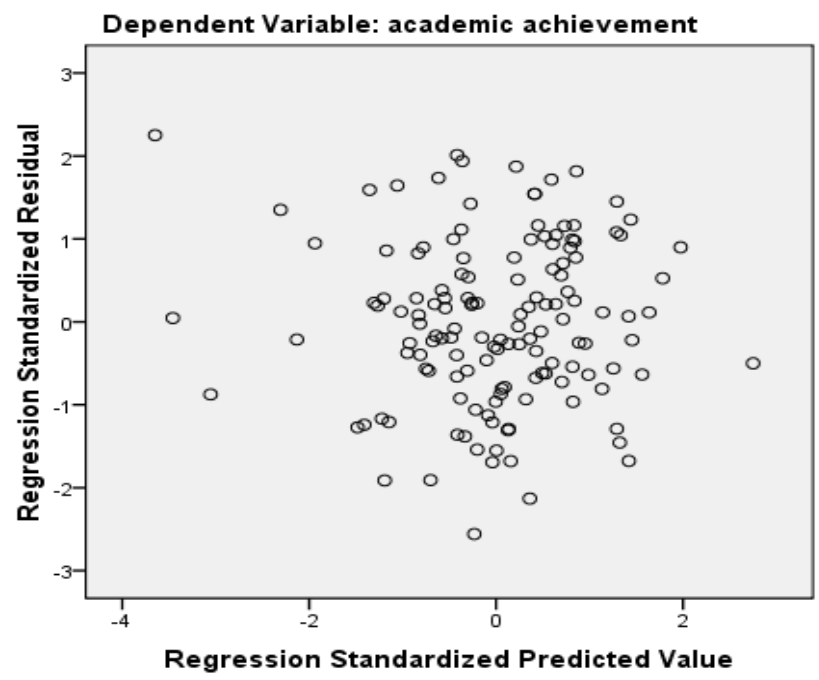

(a)

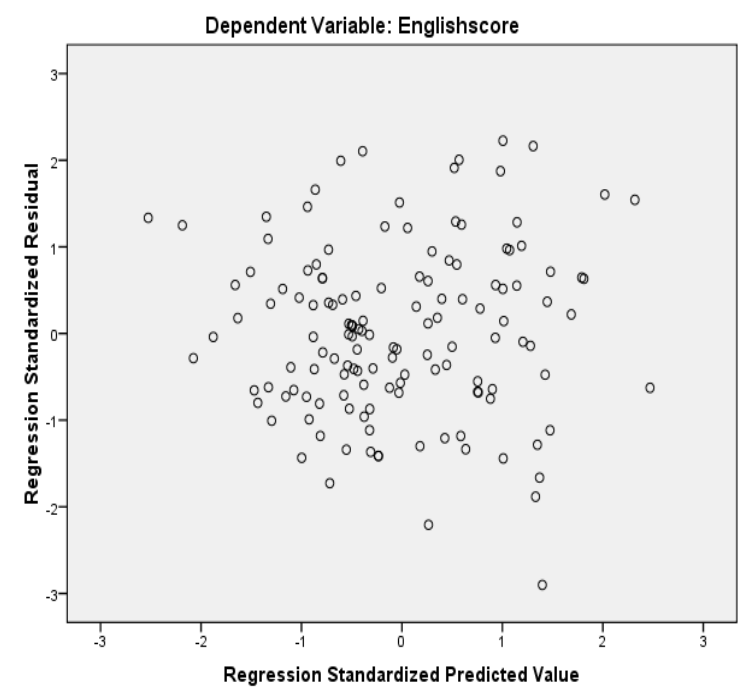

(b)

Figure 2. Scatter plots 


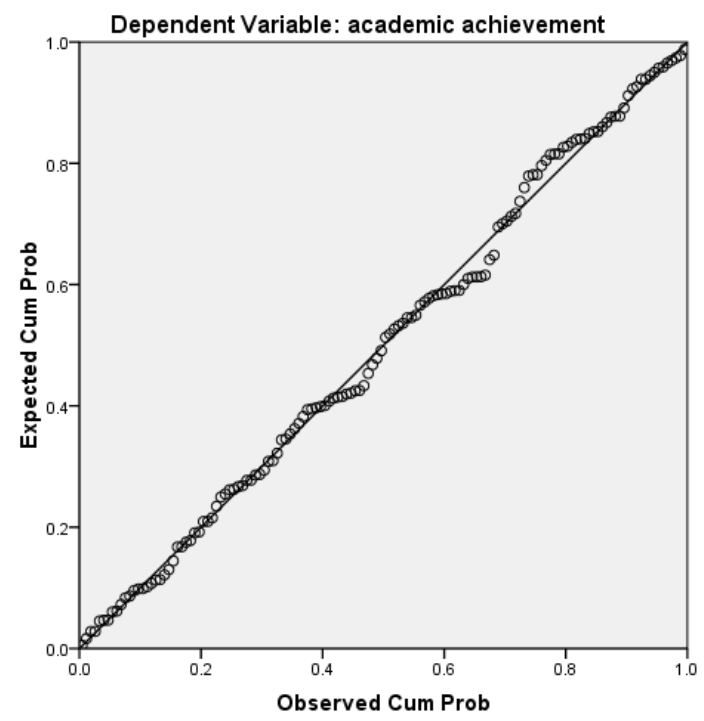

(a)

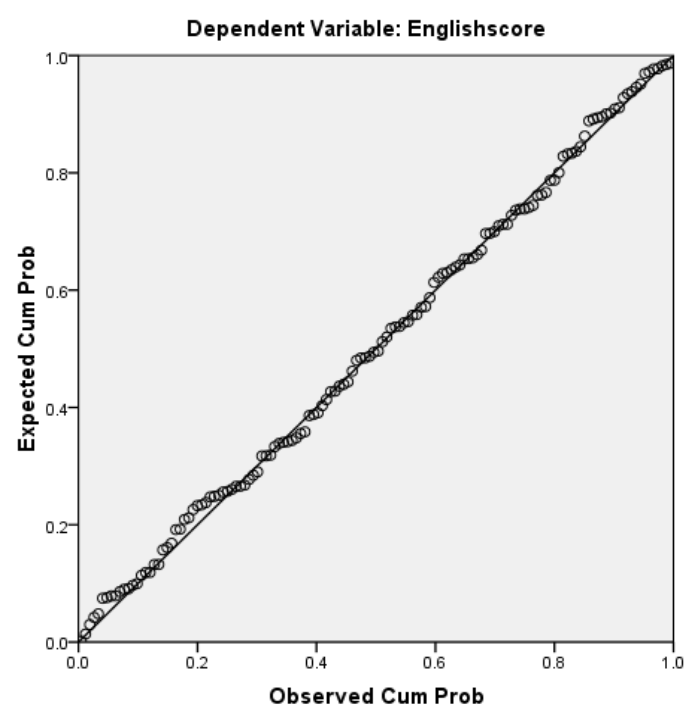

(b)

Figure 3. Normal P-P Plots of Regression Standardized Residuals 